\title{
Critical-Ethical-Thinking: A Humancentric Theory of Education in the Face of Labour-Market-Schooling in Africa
}

\author{
Bonaventure B. Gubazire'1 \\ 1 Department of Philosophy and Social Sciences, Spiritan University, Ejisu - Ghana.
}

\begin{abstract}
Leaning on a number of philosophers of education and on the researcher's experience, this paper modestly proposes a humancentric theory of education that puts a priority on enabling educators and learners to primarily develop what is termed "critical-ethical-minds" prior to seeking specialized knowledge and skills. Once this prime objective is achieved, learners would be well equipped to creatively engage with other academic disciplines in view of acquiring corresponding jobs in the life-world. This paper recommends that this theory of education is likely to produce an individual judged as intellectually emancipated and maturely articulate; capable of reasonably facing the realities of this world and Africa in particular, and of transforming his or her society into a better place to live in.
\end{abstract}

Correspondence

Bonaventure Gubazire

Email: bgubazire@yahoo.fr

Publication History

Received 22nd April, 2021

Accepted 26th May, 2021

Published online 15th June, 2021

Keywords: Education, Labour-Market-Schooling, Critical-Ethical-Thinking, Humancentric Theory of Education.

(C) 2021 The Author(s). Published and Maintained by Noyam Publishers.

This is an open access article under the CCBY license (http://creativecommons.org/licenses/by/4.0/).

\section{INTRODUCTION}

Today, in most capitalistic societies, education as a learning process tends to focus more on the production of skilled, efficient and competent professionals consistent with the labour market, while, in some way, paying less attention to their ethical development. Most institutions of higher education place more emphasis on the relationship between educational outcomes and the labour market. ${ }^{1}$ An "educated person" is not necessarily one who is integral or selfdetermining, but one who is ready-at-hand for the labour market. Sometimes, those considered to be well-educated are the very individuals behind awful attitudes and acts such as corruption, extremism, terrorism, homicide, witchcraft, etc. Other times, the so-called "educated individuals" find it difficult to think for themselves. They totally rely on other people's thoughts; lead a life characterised by puppetism, absolutely incapable of challenging political, religious, cultural beliefs and practices that do not contribute to human or societal flourishing. This raises concerns about the impact of education per se. On this premise, one may ask the following questions: What does it really mean to be an educated person? What measures should higher educational institutions in Africa put in place to ensure what may be called "proper education"?

This paper humbly proposes a humancentric (human-focused) theory of education that puts a priority on enabling educators and learners to develop what may be termed "critical-ethical-minds" prior to venturing into other fields of life. The paper bears in mind, higher institutions of learning such as colleges and universities. It will firstly analyse certain challenges faced by most educational institutions in attempting to meet the demands of modern capitalism, especially on the labour market. Secondly, it will attempt to define education within a framework of philosophy in view of capturing its etymological significance. Thirdly, it will engage with different philosophers [from ancient to postmodern times] and gauge whether their educational theories can be relevant or not to present times. Fourthly and lastly, the study proposes an educational theory that would produce an intellectually emancipated and maturely articulate person. It appeals to some philosophers of education, particularly, T.W. Moore, Robert E. Young and some African thinkers such as John Mbiti and Edward Kanyike.

\footnotetext{
Hugh Lauder \& Ken Mayhew, "Higher Education and the Labour Market: An Introduction," Oxford Review of Education 46, no.1(2020):1-9; Oluyomi Susan Pitan \& Segun Olugbenda Adedeji, "Students' Choice of Courses: Determining factors, Sources of Information, and Relationship with the Labour Market Demands in Nigeria," African Education Review 11, no.3(2014): 445-458.
} 


\section{Education}

Education, as a process of learning, should aim, first and foremost, at producing intellectually emancipated and valueladen human beings who can thereafter engage in specialised studies such as Accounting, Business Administration, Marketing, Politics, Engineering, Medicine, Law, etc. Apart from owning skills obtained from specialised studies, an "educated person" would be, in the first place, one endowed, with an ability to critically evaluate oneself in view of becoming maturely articulate. Secondly, an "educated person" would be one endowed with an ability to judiciously evaluate the knowledge acquired from a prevailing cultural milieu, or generated through studies or experience, as a yardstick for one's behaviour and action. Such a person, in collaboration with others, is likely to transform this world into a better place to live in. This undertaking presupposes a theory of education that is fundamentally humancentric. Such an educational theory and practice would aim at producing a mature, authentic, integral, sensitive, spiritual and intellectually equipped individual who deserves to be referred to as a "wise person."

Philosophers of education, in a way, endorse a type of education that puts the accent on critical-ethical-thinking as the foundation for other academic disciplines and ordinary life activities. For Moore, education should be considered as "an end itself, something intrinsically good," involving primarily the development and transformation of a person into a maturely articulate human being. ${ }^{2}$ For Young, educators should take into consideration the identity, cultural background and living standards of learners instead of simply feeding them with an already-prepared package of knowledge. ${ }^{3}$ For Kanyike, the rite of initiation, in an African context, enabled one to critically examine oneself and one's surrounding as a preparation for a new life characterised by both individual and communal responsibilities. ${ }^{4}$ For Mbiti, initiation was a rebirth into a life of maturity whereby the initiate inherited certain rights coupled with a number of obligations. ${ }^{5}$ These thinkers subscribe to a type of education that aims at equipping learners or initiates with ethical and human values prior to their engagement with other fields of life.

\section{Labour-Market-Schooling as a Challenge to Education Today}

The term "labour-market-schooling" refers to an educational system that primarily aims at producing skilled, efficient and competent professionals, viewed as economic assets, irrespective of their ethical standing. As such, an educated person is not necessarily one who embodies ethical or human values, but a person who does his job efficiently and profitably.

The world largely defines "good-life" in terms of material prosperity. Modern capitalism, which is largely characterised by private ownership of means of production, makes one believe that the more money he/she makes the more meaningful life becomes. No doubt an amount of wealth is needed for the procurement of some basic needs, but it is not the only determining factor for one's well-being. Unfortunately, this materialistic conception of human life has, in a way, affected most institutions of learning in Africa and in many other capitalistic societies on this planet. The main goal or purpose of education is to produce individuals conceived of as economic assets. Learners are basically trained to become professionally efficient and economically productive. Education can therefore not be seen as an end in itself. In other words, education is hardly conceived of as also a process of human growth during which learners ought to be enabled to develop core human values such as honesty, responsibility, respect for life, respect for elders, etc.

One should not be surprised when they discover that the so-called "educated individuals" are the very people behind dreadful acts such as corruption, stealing of state funds, human trafficking, channeling and selling off medicine meant for public hospitals, etc. It should also not be a surprise when some parents, educators and school administrators get caught up in planned vices such as bribery, nepotism or favoritism. Through bribery, a learner in class can secure higher grades he or she has not genuinely worked for. Imagine the kind of a person he or she would become! Yet, proper education is the key to human and societal flourishing. Education plays a major role not only in modeling one's character but also in equipping one with skills and knowledge that should normally enable one to live a reasonable and successful life. A successful life presupposes a viable and collaborative association with other human beings. Life is more meaningful when it is lived with and for others in just institutions.

Regrettably, today, in many institutions of learning, it is the labour market that largely determines what should be included or not in school curricula. ${ }^{6}$ While it is a reasonable and pertinent move to specialise in specific academic fields in view of securing well-paying jobs, an over-emphasis on producing graduates deemed as economic assets only can compromise the quality of education. It should be taken into account that a school is also a place of learning and nurturing core humanistic values such as integrity, love, compassion, dialogue, consideration, forgiveness, kindness, responsibility, and so on. To explain the necessity of introducing critical-ethical-thinking in educational activities, a critical analysis of the term "education" might be of great help.

\footnotetext{
Terence W. Moore, Philosophy of Education: An Introduction (London: Routledge \& Kegan Paul, 1982), 13.

Robert E. Young, A Critical Theory of Education: Habermas and our Children's Future (New York: Harvester Wheatsheaf, 1989$), 68$.

Edward Kanyike, The Principle of Participation in African Cosmology and Anthropology (Balaka: Montfort Media, 2004 ), 122.

John Mbiti, African Religions and Philosophy (Norfork: Heinemann, 1976), 121.

Pitan \& Adedeji, "Students' Choice of Courses," 445.
} 


\section{Conceptualisation of Education}

Education as a learning process encompasses a variety of theories and practices. Some scholars such as Thomas Hobbes and John Locke understand education as a means of directly transmitting knowledge and skills to learners in response to societal needs. Other thinkers such as Plato, F. Froebel and J. Dewey conceive of education as also a means of enabling learners to bring out what is within their natural endowments. The first theory of education is what characterises the traditional [classical] way of schooling, while the second theory encompasses what is considered a critical or "organic" approach to education. ${ }^{7}$ The error would be to capitalise on one educational theory - due to its economic profitableness - at the expense of other theories. This paper modestly shows that these approaches to education are not antagonists, but rather complement each other. In higher institutions of learning, critical-ethical-thinking should be prioritised over other forms of learning in order to produce the type of a person honorably considered as intellectually emancipated and maturely articulate. ${ }^{8}$

\section{What are the philosophical underpinnings of the term "education"?}

The term "education" can be used in a descriptive and normative sense. From a descriptive standpoint, education may be understood as a totality of one's experiences or what amounts to one's profile. ${ }^{9}$ Such experiences are usually reflected in one's curriculum vitae. It is to say, for instance, that Mr. Tom was educated in such and such a school, and he got such and such academic rewards. From a normative standpoint, however, the term "education" carries a reference to value. It implies the mode of being of the so-called "educated person." For instance, one may ask: Is the so-called educated person a self-emancipated, self-affirmative and a maturely articulate individual? Is he or she someone that ought to be emulated? It is precisely this normative sense of education which provides the logical starting point of an educational theory that this paper attempts to defend.

Etymologically "education" can be traced to the Latin noun educatio, which carries meanings such as instruction, tutorage, bringing up, rearing, training, etc. Two significant verbs are in turn derived from this root, namely educare and educere. Educare means to bring up, to mold or to train. It suggests an act of directly transmitting knowledge and skills to learners. The source of knowledge is external. The educator is basically the source of knowledge. He or she determines the learning process. The learner is simply a recipient. The second root educere means to lead out, to draw out or to bring out. It refers to the act of enabling a learner to bring out knowledge from within. It empowers learners to bring out their inner potentialities. ${ }^{10}$ This approach to education presupposes the existence of some innate knowledge. A great amount of knowledge springs from the learner and not from the teacher. The teacher is visibly present as a guide, just like how a midwife enables a woman to give birth.

One can already notice that these two derivatives [ educare and educere] are reflected in both the traditional theory of education and the critical theory of education. On the one hand, strict traditional schooling tends to be mechanical, authoritarian and more focused on achieving external ends such as producing, for instance, an efficient and productive engineer. The educator, in some sense, exerts intellectual power over learners. Learners simply take what the educator gives them, just like how military trainees behave and perform before their trainers. Learners appear, more or less, like "human machines" awaiting to be "programmed" for a particular goal. Education as a learning process becomes a matter of organizing desirable inputs in the form of knowledge and skills to meet, especially, the demands of the labour market.

Critical schooling, on the other hand, embraces an "organic" approach to education. ${ }^{11}$ A learner is conceived of as a living creature with material and non-material features. A learner is believed to have inherent talents and capacities that need to be nurtured. Education is, therefore, a means to bring out those talents or unique gifts inherent in the learner. Educators are supposed to devise means and create an environment that allows learners to explore and bring to fruition their natural endowments. While the traditional approach to education seems to progressively attract much attention in most capitalistic societies by its pragmatic and simplistic approach to education, it does not reflect on its own what is considered to be the fundamental goal of education which is to produce intellectually emancipated and maturely articulate graduates. Nevertheless, when critically assessed and taken together, both traditional schooling and critical schooling enrich each other at different levels of human growth. This point will be developed later.

\section{Education in Ancient and Medieval Times}

What did it mean to be an educated person in ancient and medieval times? For Socrates and Plato, man is born with a faint knowledge of the good. ${ }^{12}$ The good is that which is fundamentally desired. The good is presumed as that which

\footnotetext{
Moore, Philosophy of Education: An Introduction, 17.

Young, A Critical Theory of Education: Habermas and our Children's Future, 81.

Moore, Philosophy of Education: An Introduction, 11.

Christopher Winch \& John Gingell, Philosophy of Education: The Key Concepts, $2^{\text {nd }}$ ed. (London: Routledge, 2008), 63-64.

Moore, Philosophy of Education: An Introduction, 17.

Plato, The Dialogues of Plato Vol. 3, Trans. R. E. Allen (London: Yale University Press, 1996).
} 
promises man a certain level of fulfillment. This is evidenced by man's natural desire or inclination towards the good. Man has a faint knowledge of the good precisely because his soul once lived in the world of perfection (goodness) the world of Forms - before entering into the human body. Man commits evil because he mistakes evil for the good. A thief steals because there is a presumed good behind the act of stealing. For Socrates, no one indulges oneself in vices knowingly. Ignorance is the mother of vices. Knowledge is a virtue. To know the good is to do the good. ${ }^{13}$ Education is thus a process of liberating learners from the cave of ignorance, for it enables the learner to remember (anamnesis) the good. Educators are simply guides or "midwives." Their task is to enable learners to bring out (educere) or "give birth" to true knowledge. An educated person is, therefore, one who is capable of (1) remembering what the "soul" knew in the world of Forms before it got imprisoned in the human body, and also capable of (2) reasonably exerting control over one's bodily appetites such as hunger, thirst, sexual desires, vainglory, etc.

Like Plato, Aristotle upholds that man has the ability to carry out rationally formulated projects. ${ }^{14}$ Rationality is responsible for the proper functioning of the soul. Rationality inclines man to his proper end, which is happiness. Happiness is achieved when human rationality takes control over the irrational parts of the soul [i.e., vegetative and appetitive] to arrive at the middle ground or mean between excess and deficiency. ${ }^{15}$ An educated person is thus one who controls himself to strike the balance between excess and deficiency. One is said to be well-educated when one embodies virtues of temperance, moderation, fairness and so on.

Drawing on Platonic and Aristotelian philosophies, Judeo-Christian tradition - in the light of Augustine and Aquinas - upholds that man is the only species created in the image of God (Imago Dei). ${ }^{16}$ This is believed to be the unique mark God placed upon humanity. Only man, among God's creatures, shares with God the capacity to think and co-create. This makes man superior to other earthly creatures. If a man commits evil, it is because he has misused his free-will by deviating from the prescriptions of the moral order (natural law) set by God. Thus, a good education is one that enables man to perceive the necessity of attuning his life to the image and likeness of God. An educated person is "God fearing," one who adheres to the will of the Creator. An educated person is sensitive to matters of moral and aesthetic concern, one capable of appreciating both cosmic nature and human nature as theophanies, i.e., an occasion of divine manifestation.

One of the challenges faced by Judeo-Christian theory of education and other religious-based educational systems [like in Islam] is to distinguish between what comes from God and what is of human origin. How many wars have been fought by "educated individuals" in the name of religion? How much suffering has been inflicted on innocent people in the name of God? This is precisely why education should aim at producing intellectually emancipated and value-laden individuals. With a critical mind, coupled with a baggage of ethical values, one may judiciously tell whether a religious doctrine is God-centred or human-centred.

\section{Education in Modern and Postmodern Times}

What does it mean to be an educated person in modern and postmodern times? Rene Descartes upholds that man is fundamentally an independent thinking substance. This is expressed in his dictum: "Cogito ergo sum" (I think; therefore, I am) ${ }^{17}{ }^{7}$ The thinking "I" is the only thing that cannot be doubted. Thinking alone enables man to affirm his own existence with certainty. Education should aim at transforming learners into thinking beings. An educated person is thus one who has a regard for the importance of truth, accurateness and elegance in thinking. Kant sustains the view that man is a self-governing moral being by virtue of his rationality. Reason "recognises" a moral law and translates it into duty. ${ }^{18}$ The sense of duty discloses itself in man as a categorical imperative. Mankind should act in such a way that the maxim according to which is acted becomes a universal law. ${ }^{19}$ For instance, telling lies is categorically unacceptable. One cannot imagine a world where everyone tells lies. Acting morally entails that man recognises other people as moral agents. $\mathrm{He} / \mathrm{she}$ then treats them as ends in themselves and not as means. Thus, an educated individual embodies the sense of duty and acts according to categorical imperatives.

While Kant's approach to education carries weight, in the sense that it instils in the learner a sense of duty, it may, nonetheless, fail to produce the kind of a person that is desired. Kant's understanding of duty is somehow restrictive. It operates within a framework of categorical rules. There is no room for deliberation or discernment. Yet these are some of the human qualities that characterise an intellectually emancipated and maturely articulate person. Kant's philosophy tends to overlook consequences as valid factors in evaluating the morality of an action; yet, there are situations where the outcome may justify the act. Consider the example of a son who tells lies to hide his tenderly loving and caring father from would-be murders. In Kantian thought, the son's action is absolutely wrong. Taken categorically,

3 Plato, The Dialogues of Plato Vol. 3, 124.

14 Aristotle, Nicomachean Ethics, Book II, chapter 6, Trans. W.D. Ross (Kitchener: Batoche Books, 1999).

Aristotle, Nicomachean Ethics, Book II, chapter 6, 26.

Thomas Aquinas, The Summa Theologica, Translated by Fathers of the English Dominican Province (Westminster: Christian Classics, 1981 ), Qn 93, Art 2.

V. R. Miller et al, Rene Descartes: Principles of Philosophy (Dordrecht, Holland: D. Reidel Publishing Company, 1982 [ 1644 ]), Part 1. Art. 7.

Immanuel Kant, The Metaphysics of Morals, trans. Gregor M. (Cambridge: Cambridge University Press 1991), 48.

9 Kant, The Metaphysics of Morals, 198. 
the Kantian educational theory may end up producing graduates with a legalistic or pharisaic mentality, completely detached from reality, and unable to address concrete human experiences with diligence and understanding.

Contrary to Plato, Locke claims that man is born tabula rasa (blank slate), that is, without any knowledge at all. ${ }^{20}$ Human beings acquire knowledge through experience as they grow. The task of an educator is, therefore, to expose learners to situations or experiences that can enable them to acquire substantial knowledge and skills. Education as such is a process of "feeding" learners with skills and knowledge to effectively produce desired outcomes. Notice that Locke conceives of education in a traditional way. His theory pivots on one of the definitions of the term "education" (educare), which means to bring up, to mold or to train. The educator is basically the source of knowledge. He or she determines the learning process. The learner is simply a recipient. In the same vein, Hobbes endorses a radical and authoritarian mode of education. ${ }^{21}$ For him, human beings are naturally ferocious. Education is a means to curb their animosity. Human opinions and actions must be well monitored by the sovereign power to achieve peace and harmony. This can be achieved through rigorous civic education.

While the Lockean and Hobbesian models of education may somehow apply to infants or teenagers [ insofar as they need attentive care and a sense of direction], it, nonetheless, raises serious concerns. Since learners are absolutely dependent upon the educator or the sovereign power, are they not vulnerable to all sorts of brainwashing or indoctrination? Is this not what most terrorists and religious opportunists do to their adepts?

Unlike Locke and Hobbes who strictly consider education as an activity of "feeding" learners with skills and knowledge to produce desired outcomes, Friedrich Froebel, John Dewey and Robert Young, endorse an educational theory that seeks to involve learners in the educational process. Learners are endowed with inner aptitudes that must be brought out (educere). For Froebel, mankind is fundamentally productive and creative. Learners are inherently endowed with a divine pattern which can be brought out by a student-centred model of education. ${ }^{22}$ Learners should not be passive but active participants in their educational activities. For Dewey, learners' interests, problems and capabilities should be the starting point for any educational theory and activity. ${ }^{23}$ Learners should be allowed to participate and determine their educational outcomes. For Young, educators should take into consideration the identity, personal interests, family background and the life-world of learners instead of simply imparting on them an already-prepared package of knowledge. ${ }^{24}$ Behind this mode of education is the conviction that human beings are not "mechanical entities" to be programmed or manipulated the way one wants. Human beings are rather distinct creatures capable of growth and development. They are ignorant of certain things but also endowed with inherent aptitudes. This position on education largely corresponds with the theory of education that this paper attempts to defend.

Postmodern thinkers rigorously deny any rational foundation for theories that claim to provide an "objective" account of the world outside of discussive dialogue. People in a particular situation are the ones to decide what is objective or not. Truth is not objective but rather constructed. This is due to the fact that reality is constantly changing. Everything is in a state of flux. As such, moral norms are context-based and not universal. For Nietzsche, people must be determined and be responsible for their own actions and destinies. To conceive of them in totalizing or universalising terms is to alienate them from their own being. Education should thus aim at liberating man from "slave morality." 25

Heidegger conceives truth as self-revealing. Truth is not something fixed in a system. "Being-true (truth) means being-uncovering." ${ }^{26}$ To be Dasein (man) is to be fully aware of the possibilities of being human. It is to pursue what it means to be oneself and to constantly work out what it takes to realise one's potentialities for a good life. Elsewhere, Foucault deflates all traditional correspondent theories of truth. ${ }^{27}$ All claims to know reality are organized under the notion of power. Power resides in and is articulated through a dominant discourse. The dominant party defines the nature and conditions of knowing at any given time and place in history and imposes that knowledge upon individuals. Foucault calls for resistance to subordination through emancipatory education.

No doubt postmodern thinkers must be credited for their insistence on the contingence of reality. The world is constantly changing in all aspects of life. Postmodernists must also be credited for their insistence on the local and particular contexts to accommodate individual differences and experiences of people. What man cannot accept, however, is their rejection of generalisable principles of knowledge and human conduct. Without some external arbitration or universalisable norms like the inalienable Human Rights, human societies may end up in jeopardy. By rejecting generalisable normative assessments and putting the accent on local discursive regularities as the basis for normativity,

\footnotetext{
20 John Locke, Essay Concerning Human Understanding, (Pennsylvania: Pennsylvania State University, 1999), Book II, Chap. I \& 2.

21 Thomas Hobbes, Leviathan with Selected Variants from the Latin Edition of 1668, Edited by E. Curley (Indianapolis: Hackett, 1994C [1651]), Section 18:19, 113

22 Friedrich Froebel, On the Education of Man (Leipzig:Wienbrach, 1826), 2.

3 John Dewey, Democracy and Education (New York: Macmillan, 1916).

Young, A Critical Theory of Education: Habermas and our Children's Future, 68.

Friedrich Nietzsche, Beyond Good and Evil (Penguin Books, London 1973), 122.

Martin Heidegger, Being and Time, Trans. John Macquarrie \& Edward Robinson (Oxford: Blackwell 1962), 262.

Michel Foucault, "The Ethics of the Concern for Self as a Practice of Freedom," Essential Works of Michel Foucault, Vol 1. Ethics: Subjectivity and Truth, Ed. Paul Rabinow (New York: The New Press, 281-301, 1979), 291.
} 
one wonders how postmodernism would foresee and abate possibilities of extreme ethnic or cultural relativism capable of inspiring awful acts such as genocide, terrorism or religious fundamentalism.

Thus said, is it possible to come up with a theory of education that would take into account the contingency of reality, the elusiveness of truth, and the differences in the conception of human nature? Would such a theory apply to the African ethos?

\section{TOWARDS A HUMANCENTRIC THEORY OF EDUCATION}

A humancentric theory of education basically aims at creating emancipated and ethically sound individuals prior to their engagement in other fields of life. Moore makes a distinction between "aims" and "purposes" in education. ${ }^{28}$ While both words connote an "end," they differ in some sense. The talk of purpose refers to some external end to which the activity is directed. The talk of aim does not refer to an external end, but rather to the activity itself, to its internal end. One thing is done in order to achieve another. For example, a student learning Chinese may be asked: what are you doing? The answer might be: I am trying to master the Chinese language. Notice that the student's answer does not refer to any external end, but the activity itself. The student may be further asked: why are you doing it? The answer might be: I want to secure a job in China.

Thus, to ask the aim of education is to conceive of education as an end in itself, something intrinsically good, involving the development of a person into an emancipated and maturely articulate human being. To ask the purpose [s] of education is to think of it as a means to bring about external goods such as skilled workers, professionals, experts and so on. Consequently, education as a process of learning should be an end in itself prior to its application to various fields of life.

Interestingly, the distinction between "aims" and "purposes" in education can also be identified in some African traditional cultures. For one to become maturely articulate, one had to go through a rigorous educational process known as initiation. Initiation, as a learning process, is aimed at transforming the adolescent into a mature adult by equipping him or her with core human values. The rite of initiation was seen as a preparatory programme before one could get involved in other spheres of life. For Kanyike, the rite of initiation enabled one to examine oneself and one's surrounding as a preparation for a new life characterised by both individual and communal responsibilities. ${ }^{29}$ During initiation, many things were taught such as respect for others, especially for elders, matters related to sexuality, marriage, religion and life after death. Initiation marked a transition from childhood to adulthood. For Mbiti, initiation was a rebirth into new life. ${ }^{30}$ The initiate entered into the state of responsibility whereby he or she inherited certain rights coupled with a number of obligations. On certain occasions, the initiate could sit and discuss with elders matters pertaining to the wellbeing of the society.

Beneath the pedagogical exercise of initiation was an African philosophical precept that not all human beings are human persons. Personhood was necessarily linked with ethical responsibility. Personhood was a prerequisite for an individual's involvement in essential responsibilities like leadership as well as procreation through marriage. Personhood was often associated with the element of being truly human. For one to be identified as a human person in the proper sense of the term, one's conduct or way of being had to correspond with a certain ethical standard. For the Akan people of Ghana, an individual whose conduct was absolutely wicked, selfish, cruel, stingy, ungrateful for everything done by others, that individual was said not to be a person (Onnye onipa). ${ }^{31}$ Similarly, for the Bakiga people of Uganda [as in many Bantu cultures], an individual whose conduct was absolutely disrespectful and unbearable, was considered as lacking Ubuntu (personhood or the essence of being truly human). An individual of a kind was not supposed to mingle with other people. As such, education in the African ethos prioritised human development. A human person was expected to display certain ethical virtues such as respect for elders, kindness, generosity, compassion, etc., before venturing into other fields of life. An individual with such qualities would be conceived of as maturely articulate, worthy of being trusted. One who lacked those virtues would not fully participate in community activities or play significant roles in society.

Put into the present context, education should aim at producing reasonable and value-laden human beings before focusing on other specialized studies such as Accounting, Business Administration, Politics, Engineering, Law, and so on. How can a state fight against common vices such as corruption, bribery, mishandling of public funds, etc., when civil servants themselves have no sense of integrity? How can an educational institution attain its goals when educators and learners are not honest with each other? How can educators commit themselves to enable learners to become responsible and mature human beings when educators themselves are not mature and have no sense of compassionate responsibility? This is precisely why education should aim at creating, before anything else, an ethically

\footnotetext{
$\overline{28}$ Moore, Philosophy of Education: An Introduction, 12-13.

29 Kanyike, The Principle of Participation in African Cosmology and Anthropology, 122.

Mbiti, African Religions and Philosophy, 121.

1 Kwame Gyekye, Tradition and Modernity: Philosophical Reflections on the African Experience (Oxford: Oxford University Press, 1997$), 49$.
} 
"sound person," one who is capable of critically examining himself, as well as his cultural-religious or political milieu, in view of fostering viable avenues for meaningful co-existence. It is there and then that the person will be of great help in achieving worthwhile external ends in specific jobs. But what kind of learning process would create such a person?

\section{Education and Critical-Ethical-Thinking}

In this section, the abbreviation CET will be used to refer to the expression "Critical-Ethical-Thinking." The "criticalethical-thinking" defended in this paper suggests an ability of a person to rationally and judiciously evaluate the knowledge acquired from one's cultural milieu, or generated through studies or experience, as a yardstick for one's behaviour and action. It also refers to one's ability to evaluate oneself in view of bringing out or nurturing one's potentialities for a better life shared with others. In other words, CET is a continuous process of examining life, knowledge, beliefs and the realities that surround mankind. Learners with CET will not be seen as professionals or economic assets only. They will be seen as people worthy of trust, people who display essential human values that build viable societies. As echoed earlier, CET is not an isolated goal of education, but rather a hub around which all other educational ends cluster.

The importance of CET in education is not a new phenomenon. For Plato, as mentioned earlier, the educated man was one empowered to "give birth" to knowledge from within. Some academic disciplines were selected for this purpose. These included Mathematics and Philosophy. For Plato, such academic disciplines were meant to sharpen the mind of the learner, to enable him or her to grasp the knowledge of the Forms, the knowledge of true reality. A person of that intellectual level was eligible for leadership roles, he or she would be guardian and ruler of the state. ${ }^{32}$

Socrates once said: "an unexamined life is not worth living." ${ }^{33}$ Experience has shown that in those societies where individuals have no capacity to examine their lives, people tend to adhere to certain cultural practices that are intrinsically odd, but which the community considers [at that moment] suitably true. How many societies in Africa still consider pre-arranged or forced marriages as a rightful practice? How many societies in Africa still consider Female Genital Mutilation (FGM) as the best practice to guarantee fidelity among couples? Again, how many people in this world are still intellectually and psychologically enslaved by witchcraft and other sorts of superstitious beliefs? How many people still believe in false prophets, false diviners, etc., who unfortunately take advantage of people's ignorance to enrich themselves materially? This is precisely why CET seems paramount in empowering people to avoid swallowing commonly accepted cultural or religious assumptions without continuously submitting them to the sieve of critical thinking to gauge whether they are appropriate or not, true or false.

Human experience shows that most evils in African societies and elsewhere are politically caused. Political evils stem from the paradoxical nature of political power. Political power [ which is good in itself], if left unchecked, can be misused. There is a saying that power corrupts, and absolute power corrupts absolutely. Quite often, political evils arise when citizens, even the most educated ones [for one reason or another], decide to keep silent or to be politically indifferent before lamentable situations of injustice. CET would instill in people [without inciting them to violence] a sense of commitment towards their ethical obligations in politics. It would empower people to realise that their active participation in politics is not an option, but a necessity.

\section{RECOMMENDATIONS}

Education ought not to be largely determined by the labour market. It should rather aim, first and foremost, at producing an intellectually emancipated and value-laden human being before he or she can assiduously engage with specialised studies such as Accounting, Business Administration, Politics, Engineering, Journalism, Medicine, Law, etc. Educators should enable students to develop a substantial level of critical consciousness. Learners should be enabled to bring out (educere) knowledge from their natural endowments. For this to take place, foundational academic disciplines such Logic, Ethics, Epistemology, Philosophy of Man, Cultural-Religious Studies, etc., ought to be placed in educational curricula. Teaching, as an educational activity, should be participatory. Platforms of dialogue should be created to allow learners to openly ask questions for clarification, or intervene in the learning process to contribute their own ideas. A climate of freedom should equally be created to allow learners not only to freely talk about themselves but also to feely reflect and challenge the status quo when it is necessary.

Taken seriously, critical-ethical-thinking (CET) can enable learners to constantly evaluate their actions and behavior in conformity with not only the norms of their particular societies, but also with universal moral standards. As such, learners are likely to become productive citizens in their own societies and responsible human beings at a global level. As mentioned earlier, a "well-educated person" is one empowered with an ability to continually evaluate oneself and one's environment to improve the standards of living of all. The task of educators at all levels is to provide learning skills or methods that can motivate learners to develop critical-ethical-minds as a tool for engaging with other

\footnotetext{
Plato, The Republic, Tans. Desmond Lee, Second Edition with new Introduction (London: Penguin Classics, 2007$), 204$.

33 Plato's Apology (38a5-6) in Plato, Euthyphro. Apology. Crito. Phaedo. Phaedrus, Trans. Harold North Fowler (Cambridge: Harvard University Press, 2005), 133.
} 
educational ends. This presupposes, however, that educators themselves are endowed with critical-ethical-minds. How would one give what one does not have?

\section{CONCLUSION}

This paper has attempted to propose a humancentric theory of education that puts a priority on empowering educators and learners to develop "critical-ethical-minds" in order to judiciously face the realities of this world. Education, as a process of learning, should be seen as an end in itself before orienting it to other educational outcomes. It has been noted that only a humancentric educational scheme is one likely to produce a mature, authentic, integral, skilled, prudent, sensitive, spiritual and intellectually equipped individual, one that deserves to be called a "wise person." Nevertheless, such a theory of education presupposes the existence of democratic platforms that allow educators, learners and administrators to freely express themselves and create together school curricula and other educational guidelines while prioritising those tools that enable learners to become critical-ethical-thinkers. Unfortunately, not all societies in African and elsewhere adhere to the principles of participatory democracy. This is indeed a stumbling block on the journey towards a humancentric educational practice.

\section{ABOUT AUTHOR}

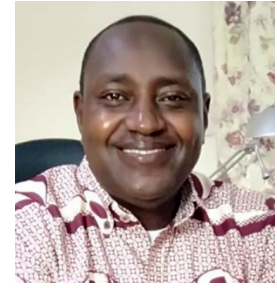

Dr. Bonaventure B. Gubazire is currently a Lecturer in Philosophy at Spiritan University CollegeEjisu (Ghana). He is a Catholic priest belonging to the Society of Missionaries of Africa (M. Afr). $\mathrm{He}$ also serves as formator (educator) of the Missionaries of Africa candidates. He holds a Ph.D. in philosophy awarded by the University of San Carlos- Cebu (Philippines). Dr. Gubazire has served as a missionary in France, Mozambique, Malawi and in the Philippines. He has lectured in philosophy at Inter-congregational Institute (ICI) Balaka, an affiliate of the Catholic University of Malawi. He

has also served as formator (educator) of the Missionaries of African candidates in Malawi and in the Philippines. He has published a book on Communitarian Cultures, and presented scholarly papers in various universities. His research interests are focused on Education, Ethics and Religions.

\section{BIBLIOGRAPHY}

Aquinas, Thomas. Summa Theologica. Translated by Fathers of the English Dominican Province. Westminster: Christian Classics, 1981.

Aristotle. Nicomachean Ethics. trans. W.D. Ross. Kitchener: Batoche Books, 1999.

Dewey, John. Democracy and Education. New York: Macmillan, 1916.

Foucault, Michel. "The Ethics of the Concern for Self as a Practice of Freedom." Ethics: Subjectivity and Truth (Essential Works of Michel Foucault, 1954-1984, Vol 1) Ed. Paul Rabinow. New York: The New Press, 1979.

Gyekye, Kwame. Tradition and Modernity: Philosophical Reflections on the African Experience. Oxford: Oxford University Press, 1997.

Heidegger, Martin. Being and Time. Trans. John Macquarrie \& Edward Robinson. Oxford: Blackwell, 1962.

Hobbes, Thomas. Leviathan with Selected Variants from the Latin Edition of 1668. Edited by E. Curley (Indianapolis: Hackett, 1994C [1651]).

Kant, Immanuel. The Metaphysics of Morals. Trans. Gregor M. Cambridge: Cambridge University Press 1991.

Kanyike, Edward. The Principle of Participation in African Cosmology and Anthropology. Balaka: Montfort Media, 2004.

Lauder, Hugh \& Mayhew, Ken. "Higher Education and the Labour Market: An Introduction." Oxford Review of Education 46, no.1(2020):1-9.

Locke, John, Essay Concerning Human Understanding. Pennsylvania: Pennsylvania State University, 1999.

Miller, V. R. Rene Descartes: Principles of Philosophy. Dordrecht, Holland: D. Reidel Publishing Company, 1982.

Moore, T.W. Philosophy of Education: An Introduction. London: Routledge \& Kegan Paul, 1982.

Nietzsche, Friedrich. Beyond Good and Evil. Penguin Books, London 1973.

Pitan, Oluyomi Susan \& Adedeji, Segun Olugbenda. "Students' Choice of Courses: Determining factors, Sources of Information, and Relationship with the Labour Market Demands in Nigeria." African Education Review 11, no.3(2014): 445-458. 
Plato. The Dialogues of Plato Vol. 3, Trans. R. E. Allen. London: Yale University Press, 1996.

. Euthyphro. Apology. Crito. Phaedo. Phaedrus. Trans. Harold North Fowler. Cambridge: Harvard University Press, 2005.

Winch, C. \& Gingell, J. Philosophy of Education: The Key Concepts. $2^{\text {nd }}$ ed. London: Routledge, 2008.

Young, E. Robert. A Critical Theory of Education: Habermas and our Children's Future. New York: Harvester Wheatsheaf, 1989. 